- around it makes that necessary."

"We are waiting patiently and doing our best to plan," adds Matthew Lee, interim associate vice-chancellor in Louisiana State University's office of research and economic development in Baton Rouge, "but in the absence of an RFP we're kind of constrained."

Other researchers have all but given up on seeing the money. "It's as far back on the stove as I can put it," says Tracy Villareal, a marine scientist at the University of Texas at Austin in Port Aransas. "We've already had most of December and all of January wasted waiting on this. I just can't afford to be sitting around and idly waiting for this thing to come out."

Ralph Portier, an environmental scientist at Louisiana State University, fears that crucial research opportunities - such as gathering some key baseline data - have already been missed. He hopes, however, that there is still time to conduct work needed to understand Deepwater Horizon's long-term legacy, and says that the delays may help to generate proposals that are informed by the latest information about the spill's effects.

Like many researchers, Nature found it difficult to get information about the GRI's progress. Council members and GMA leaders contacted by Nature said that Colwell was the only public spokesperson for the initiative; she in turn was unavailable for interview for several weeks.

Last week, however, Colwell said that an initial RFP, aimed at consortia addressing any of the five key themes, might be released as soon as next week. She expects that Gulf research institutions will be involved in these consortia, although there will be no requirement for such participation. A second RFP targeted at individual scientists and smaller groups will be released later this year. The proposal review process will be modelled on a well-established system used by the National Science Foundation.

But the council still needs to finalize protocols for data management, and how time on research vessels will be allocated, before the first RFP can be released. Colwell says that buying a dedicated ship is not an option, but that a long-term lease is possible. She declined to give specific details about the challenges of developing the RFP, but says that the delays were largely due to expanding the council's membership and gathering everyone for a first meeting, which happened in December. Despite the slow progress, "I think that the outcome will be received with satisfaction by the scientists", she says.

Others are not so sure. "Events to date raise serious questions about whether the proper structures and organizations are in place to

$\rightarrow$ NATURE.COM

For more on

Deepwater Horizon: go.nature.com/oilspill manage this process," says Villareal. "I am not optimistic about a speedy and forthright outcome."

INTELLECTUAL PROPERTY

\title{
Licence rules hinder work on rare disease
}

\section{Animal model off-limits to Rett-syndrome researchers.}

\section{BY ERIKA CHECK HAYDEN}

S tashed away somewhere in a freezer in Cambridge, Massachusetts, is a mouse embryo that Etienne Joly would dearly like to get his hands on.

Joly is an immunologist based in Toulouse, France, with a keen interest in Rett syndrome, an incurable and debilitating disease that almost exclusively affects young girls. The mouse, developed by a team at the Novartis Institutes for Biomedical Research in Cambridge, carries a fluorescently tagged version of the gene that is mutated in the disease. It is the perfect tool, Joly says, for testing an idea he has about Rett syndrome. But a thicket of legal restrictions puts the mouse off-limits to anyone outside Novartis, even though scientists at the company are no longer using the model in their work on Rett syndrome.

"All scientists and families are asking for is the right to look into this disease and to try to understand it better," says Joly, who has embarked on a letter-writing campaign against the restrictions. "And when you know that there is a tool, but you can't use it because some lawyer says that you can't have the materials, then you get angry." Scientists and experts in intellectual-property issues say that the case shows how science can be impeded when onerous licensing rules govern the sharing of research materials.

Girls with Rett syndrome are healthy as

\section{LIMITED ACCESS}

A 2007 survey examined what materials researchers requested from other labs.

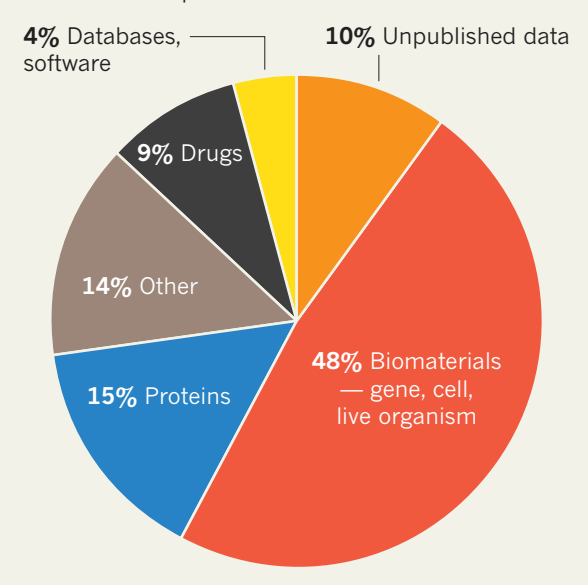

babies, then progressively lose the ability to speak, move, eat and breathe normally. Because the disease is rare, affecting just one in 10,000 to 20,000 girls, it is an unattractive target for drug companies. Academic researchers have picked up the slack, and the field has moved at breakneck speed in recent years, from the 1999 discovery that defects in the gene $M E C P 2$ cause the disease, to clinical trials of possible treatments today.

Yet no one knows how the mutation causes the disease. A few years ago, Joly, who works at the Institute of Pharmacology and Structural Biology, came up with what he calls a "slightly unconventional" idea that the Rett-syndrome gene might have a role in regulating immune responses in the central nervous system. To explore his hypothesis, Joly needed an animal model that would allow him to trace where the gene is expressed.

In 2008, Joly learned about the engineered mouse. Led by molecular biologist Cecile Blaustein, the Novartis team had joined a copy of the mouse Mecp2 gene to a copy of the gene that makes enhanced green fluorescent protein (EGFP) to produce an animal in which the gene's activity can be traced throughout the brain and body (R. S. Schmid et al. Neuroreport 19, 393-398; 2008).

But after three years of trying, neither Joly nor any other Rett-syndrome researcher has been able to gain access to the mouse. When researchers asked to share it, Blaustein and her
Were requests fulfilled?

By academics

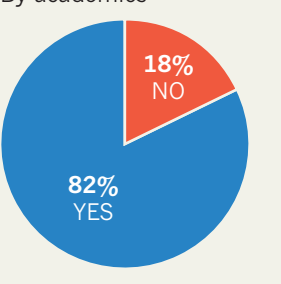

By industry
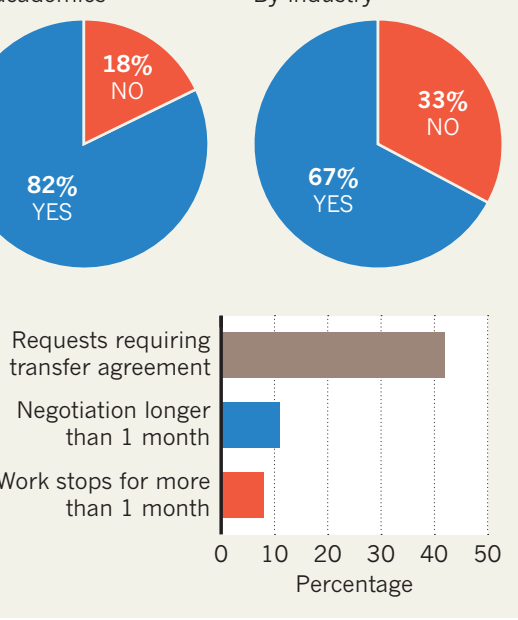


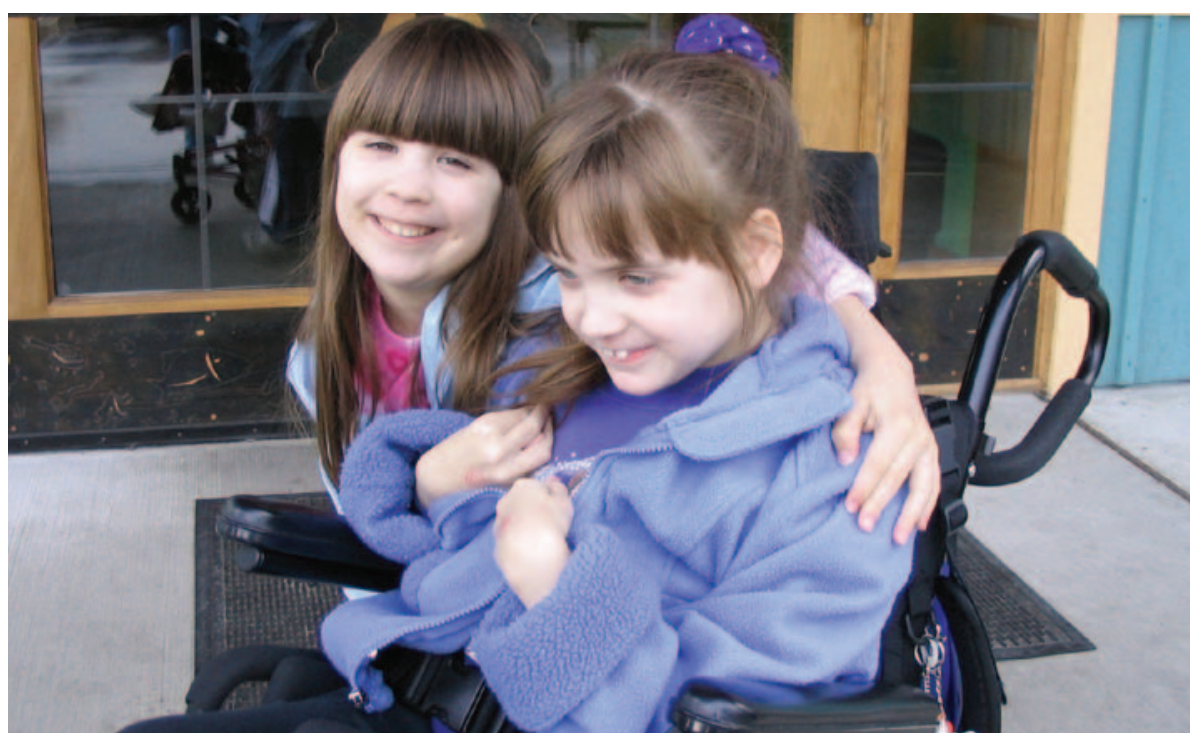

Families of young girls with Rett syndrome want barriers lifted to speed research on the disease.

colleagues said that they would have liked to but couldn't because of the terms of Novartis's licence on EGFP, which it obtained from GE Healthcare.

Novartis and GE have been unable to negotiate a way to share the mice, says Jeff Lockwood, spokesman for the Novartis Institutes for Biomedical Research - even though Novartis has ended its research project on the mice.

When Monica Coenraads, executive director of the Rett Syndrome Research Trust in Trumbull, Connecticut, tried to broker an agreement to share the mice, GE and Novartis asked the US National Institutes of Health (NIH) in Bethesda, Maryland, to distribute the mice through its Mutant Mouse Regional Resource Centers. But Lili Portilla, senior adviser for technology transfer at the NIH National Center for Research Resources, which funds the resource centre, says that GE placed such burdensome terms on the sharing that the $\mathrm{NIH}$ eventually gave up. For instance, researchers would not have been allowed to share the results of their research with the NIH, says Portilla.

GE spokesman Conor McKechnie blames the "third parties" from which GE gained the rights to the EGFP protein for the onerous licensing requirements. But David Einhorn, house counsel at the Jackson Laboratory in Bar Harbor, Maine, which distributes mice to researchers around the world, questions GE's contention. He points out that many other mouse models that incorporate the gene for EGFP have been made and shared without objection from GE or from the institutions that originally discovered and licensed the EGFP patents.

Researchers have had trouble sharing

ONATURE.COM

For a Commentary on the impact of licensing rules see: go.nature.com/sgcjih materials from other academic labs were not fulfilled (see 'Limited access') - almost twice as many as found in a survey taken during the 1990s. For materials requested from industry, the 2007 study found, one-third of academics' requests were declined (J. P. Walsh, W. M. Cohen and C. Cho Res. Pol. 36, 1184-1203; 2007).

Companies that don't want to share their resources don't usually publish papers describing them, says lawyer Tania Bubela of the University of Alberta School of Public Health in Edmonton, Canada. A publication changes the picture, she says. "The obligation of publication is to make your data and reagents available, so that people can replicate the results."

With no sign of a resolution, other labs have resorted to remaking the mouse model. Adrian Bird, director of the University of Edinburgh's Wellcome Trust Centre for Cell Biology, UK, says that his lab has re-engineered the mice and will distribute them through a repository, such as the Jackson Laboratory, as soon as his colony is large enough.

Bird and others say that it is unfortunate that scientists have had to delay research on the syndrome and spend money to regenerate a model that could already be in use.

"If you were to ask the families of people affected by this disease, they would say that every minute counts," says Bird.

\section{CORRECTION}

The News Feature 'The Genome Finishers' (Nature 462, 843-845; 2009) incorrectly states that a gap in the reference sequence of chromosome 4 was a deletion flanked by large gene duplications. The gap was an assembly error caused by attempting (and failing) to merge two alternative versions of gene sequence, which then erroneously appeared in the reference as large duplications in the UGT2B17 region. 